\title{
EL DECIR RELEVANTE Y EL SENTIDO DE LA MÍMESIS (SEGÚN FELIPE MARTÍNEZ MARZOA)
}

\author{
Robert CANER-LIESE \\ Universitat de Barcelona \\ robertcaner@ub.edu
}

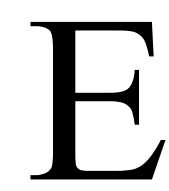

119 de diciembre de 1967, en la biblioteca del departamento de teoría literaria de la universidad de Berlín, Paul Celan ofreció ante un reducido público una lectura de poemas. El acto había sido organizado por Peter Szondi quien invitó personalmente a los asistentes, unas quince personas, para evitar los disturbios que se habían producido unos meses antes cuando Theodor W. Adorno, también invitado por Szondi, empezó su conferencia ante el nutrido público que llenaba el aula magna de la universidad berlinesa. Además de la carga significativa que pudiera tener la visita de Celan a Berlín, o el encuentro de Celan y Szondi, hay un detalle muy concreto de este acto que me gustaría destacar y comentar, ya que nos puede servir de introducción al tema que nos va a ocupar en este ensayo. El relato de uno de los asistentes a la lectura de poemas de Celan refiere la lacónica fórmula que utilizó Szondi para presentar a su invitado. Szondi se limitó a decir: «Der Dichter spricht» (Janz, 2001/02: 337), una frase que podríamos traducir por «el poeta habla» o «el poeta va a decir». Lo que llama la atención en esta frase es la especial y significativa concentración en el verbo 'decir' que se consigue al no satisfacer las expectativas del previsible modelo sujeto-objeto, es decir, del modelo de pensamiento que nos hace esperar la presencia de alguien que hace o produce algo y, por tanto, también la referencia a algo que sería el resultado de ese hacer o producir. En el contexto que aquí nos ocupa, la aplicación del modelo mencionado implicaría hablar del escritor o del poeta, así como del texto que ha sido escrito y que va a ser leído ante un atento público. La frase de Szondi consigue evitar ambas cosas: ni habla de un autor concreto ni menciona obra alguna que fuera el resultado del hacer o producir de este autor. Szondi no dice nada parecido a las fórmulas previsibles para este tipo de actos como podría ser, por ejemplo, «es para mí un honor poder presentar a Paul Celan que ha venido de París parar leernos unos poemas de su última obra que lleva por título etc.». De este modo, se produce una concentración máxima en el 'decir', pues no se presenta una obra, ni tampoco una persona, sino que se anuncia algo que va a acontecer, como si fuéramos a presenciar un decir que por ser logrado, poético, convierte a la persona que habla en poeta. 
Justamente esta concentración máxima en el 'decir' es un tema central de la obra de Felipe Martínez Marzoa sobre el cual va a tratar este trabajo. El decir del que se ocupa Martínez Marzoa con inusitada y ejemplar intensidad no se sitúa, sin embargo, en la modernidad, sino en la Grecia arcaica y clásica, y se podría identificar con aquello que llamamos los 'géneros literarios'. Incluso una ojeada superficial por sus obras confirmará que éstas, efectivamente, tratan de un modo asiduo cuestiones relacionadas con el poema épico, la poesía, la comedia, la tragedia, la narración o el diálogo, y, en algún caso, podemos incluso constatar que la cuestión del género literario aparece ya mencionada en el título mismo de obras como El saber de la comedia, La cosa y el relato o Ser y diálogo. Pero el decir del que se ocupa Martínez Marzoa, como tendremos ocasión de ver, no puede considerarse como uno más de los objetos propios y específicos de la moderna teorización del fenómeno literario, y esto no sólo porque sea un anacronismo hablar de géneros literarios en relación a un contexto histórico en el cual estas distinciones todavía no existen, sino por razones más profundas. La investigación de Martínez Marzoa se concentra en lo que él llama 'el decir griego', una expresión con la cual se refiere a un decir relevante o excelente en su condición misma de decir que tiene lugar o acontece en la Grecia arcaica y clásica. De este decir relevante irán surgiendo posteriormente los géneros literarios y surgirá también la poesía y la filosofía como dos formas discursivas claramente diferenciadas. El punto de partida de la investigación es, sin embargo, la ausencia de estas distinciones que para nosotros son lo habitual. Pero además de iluminar este remoto origen de los géneros literarios, el tratamiento que recibe el decir relevante en la obra de Martínez Marzoa nos ayudará también a entender la noción de mímesis sobre la cual trata el libro X de la República en el cual, como es bien conocido, Platón lanza una feroz crítica contra los «poetas trágicos» y la «poesía imitativa» en general (595b-c) ${ }^{1}$. El pasaje platónico es ciertamente extraño e irritante, además de paradójico, ya que el libro X de la República, un texto fundamental para la historia de la estética y de la crítica literaria, pretende demostrar que la poesía es mera y engañosa apariencia que nos aleja doblemente de la verdad y que su fascinante efecto no es otra cosa que peligroso alimento que fortalece la parte irracional del alma. Como consecuencia de la argumentación platónica se concluye que el decir filosófico es el único garante de la verdad, mientras que la poesía imitativa debe ser expulsada de la ciudad ideal. A pesar de que la argumentación platónica contra los poetas miméticos es sorprendente, e incluso algo sospechosa a causa de su carácter en exceso evidente, el libro X de la República resulta especialmente interesante por el hecho de tratar un tema tan importante para la estética y la teoría literaria como es la cuestión de la mímesis, esto es, la relación del arte con la realidad o, dicho de otro modo, la cuestión del contenido de verdad del arte. Así pues, el 'decir relevante' y la 'mímesis' estarán en el centro de mi exposición. Y para responder a la pregunta acerca de la naturaleza del 'decir relevante' haremos el rodeo por una segunda pregunta que ya ha quedado apuntada más arriba y que también es fundamental para abordar, aunque sea indirectamente, el tema de la mímesis: ¿por qué la investigación que desarrolla Martínez Marzoa, como él mismo hace notar (Martínez Marzoa, 2006: 11), no es propiamente teoría de la literatura, ni teoría de los géneros literarios, ni estética, a pesar de que hable de la comedia, de la tragedia o del relato?

\footnotetext{
${ }^{1}$ Citaré la versión castellana de Conrado Eggers Lan, 1998.
} 
A lo largo de su obra, Martínez Marzoa despliega una minuciosa interpretación y reconstrucción de la historia de unos decires relevantes propios de la Grecia arcaica y clásica que el autor, además de relevantes, también llama insolentes o impertinentes porque en ellos se produce la tematización de algo ya siempre presupuesto: la insolencia de estos decires consiste, pues,

\begin{abstract}
[...] en que se vuelva o se quiera volver relevante aquello que en todo caso está ya supuesto y que, por lo tanto, siempre ya ha quedado atrás, digamos: que quiera hacerse relevante el juego mismo que siempre ya se está jugando. Esta insolente pretensión puede encontrarse de una manera o de otra en todo el decir griego (arcaico o clásico) que conocemos, pero es en Platón donde por primera vez cristaliza en un propio y específico [y sostenido] modo de decir (Martínez Marzoa, 1996: 19-20).
\end{abstract}

Pero donde verdaderamente se percibe la gravedad de tan insolente y temeraria pretensión será en sus consecuencias, ya que la tematización del juego que ya siempre se está jugando provoca la pérdida de aquello que ha comparecido y ha sido tematizado en el decir. El vuelco es tan radical que como consecuencia del mismo nosotros nos encontramos en un mundo, el moderno, en el que lo por de pronto habitual aparece como extraño e incluso inconmensurable con el mundo griego. Entre nosotros y los griegos parece haberse interpuesto una distancia insalvable y, sin embargo, nuestro ser modernos resulta del vuelco que se puede rastrear en esos decires relevantes griegos que en cierto modo culminan con Platón, el pensador que sistematiza la insolencia y cuya obra establece aquellas distinciones entre discursos que para nosotros, los modernos, constituyen el punto de partida:

Desde después de Platón ciertos textos griegos anteriores a él se interpretan como especialmente vinculados a esa pretensión, pero esos textos son trozos de tradiciones poéticas diversas, de géneros poéticos diversos. La «filosofía» anterior a Platón no sólo es fragmentaria en el sentido de que se conserven meramente fragmentos y no obras enteras, sino que lo es también en el sentido de que se trata de una colección a posteriori de trozos de géneros varios (Martínez Marzoa, 1996: 19).

Para entender este vuelco y esta pérdida podrá ser útil empezar haciendo mención de algunos ejemplos que ponen de manifiesto el abismo que nos separa del mundo griego, ejemplos de formas de comprender la realidad que a nosotros, los modernos, nos parecen lo más natural, en el sentido de que ni se nos ocurre imaginar que la cosa en cuestión pueda ser concebida o experimentada de otro modo, y que, sin embargo, cuando uno se acerca al mundo griego, descubre que esos mismos fenómenos pueden presentarse de un modo francamente distinto. Y descubre, sobre todo, que aquello que parece lo natural es, en realidad, el resultado de una historia y que, por lo tanto, no es en absoluto natural. Nosotros, los modernos, vivimos en un mundo en el que distinguimos constantemente entre sujeto y objeto y en el que concebimos la cuestión de la verdad o del saber, es decir, la respuesta a la pregunta ‘qué es...?', como una cuestión de concordancia que se puede establecer entre un enunciado y la realidad, a la vez que concebimos el enunciado como la expresión o la objetivación de una realidad mental que llamamos representación; vivimos asimismo en un mundo en el cual existen textos o en el cual el lenguaje es imaginado como una secuencia de palabras escritas o pronunciadas que, además, hemos convertido en un objeto de estudio como cualquier otro objeto de los que son analizados por alguno de los múltiples saberes especializados existentes; vivimos asimismo en un mundo en el cual nos parece también incuestionable la existencia de una realidad anímica o interioridad con sus propios 
y cambiantes estados de ánimo los cuales a su vez pueden ser expresados mediante artefactos que llamamos obras de arte y que admiramos por su belleza o cualidad estética; o, para ir terminando la serie de posibles ejemplos, nosotros hablamos con toda naturalidad del espacio y del tiempo anteponiéndole al sustantivo ese artículo determinado como si el espacio y el tiempo fueran efectivamente algo así como una pasta única e infinita. Todas estas obviedades acerca del saber, del lenguaje, el tiempo y el espacio, o la belleza, son obviedades para nosotros. Las dificultades hermenéuticas con las que topamos cuando nos acercamos a Grecia proceden de la diferencia entre puntos de partida: lo que allí es por de pronto lo obvio es algo completamente distinto a aquello que posee el carácter de obvio en la modernidad.

Entre las cuestiones mencionadas la más importante y fundamental es la cuestión del saber y la verdad. Para nosotros los modernos la pregunta ‘¿qué es...?’ remite de forma inmediata al enunciado, esto es, a la secuencia de palabras que constituyen la definición en la cual se dice lo que aquella cosa supuestamente es. Explicamos o logramos captar de un modo objetivo la realidad en la medida que la representación o el concepto enunciado de alguna manera establece un vínculo de concordancia con la realidad, es decir, la cosa conocida «se reconoce en una esfera que [...] ya no es su propio y mismo ser.» (Martínez Marzoa, 2007: 20) En la tradición griega, en cambio, las palabras que traducimos como 'saber' designan cosas del tipo:

[...] 'ser capaz de habérselas con', destreza o pericia; no hay, por ejemplo, diferencia a este respecto entre epistéme o tékhne. [...] No opera en griego clásico noción alguna de un 'saber' enunciativo o tético. Es, pues, en el puro y simple andar con las cosas, en el que estas no se tematizan, donde propiamente hay el aparecer o el tener lugar cada cosa como lo que ella es (Martínez Marzoa, 1996: 15-16).

En su obra El decir griego insiste Martínez Marzoa de nuevo en esta cuestión central para su investigación aportando un ejemplo muy iluminador que clarifica en qué medida el modelo sujetoobjeto, que para nosotros modernos es el inmediato y habitual, no es aplicable en el contexto griego:

[...] el griego entiende el andar-con y habérselas-con, el manejar, operar y servirse-de, como reconocimiento del ser propio de la cosa, como dejar-ser [...], de manera que, por ejemplo, cortar es reconocer como inherente a la cosa misma una cierta división en partes, y propiamente sólo corta el que 'sabe por dónde cortar', no el que corta 'por donde quiere' o 'por cualquier parte'; esto es relevante porque irremediablemente nosotros, modernos, entendemos en cambio el operar y manejar de manera que tanto más maneja u opera (digamos: tanto más se 'puede') cuanto más se puede hacer de cualquier cosa cualquier otra, cuanto menos limitado se está por un ser propio de la cosa, cuanto más se puede hacer 'lo que se quiera'; irremediablemente y con verdad, pues no es sólo que lo 'entendamos' así, sino que en moderno es en efecto así (Martínez Marzoa, 2006: 27).

Como ya ha quedado apuntado, esta concepción del saber se pone también de manifiesto en un modo distinto de entender el lenguaje que se puede expresar de la siguiente forma: «el 'objeto directo' del verbo decir no es un 'dicho' que pudiese concertar o no con la cosa, sino que es la cosa misma.» (Martínez Marzoa, 2006: 17) ${ }^{2}$ Afirmación ciertamente extraña para un moderno pero que tiene su sentido. El decir la cosa misma significa que el que habla o el que dice no es aquel que emite enunciados o pronuncia palabras cuyo contenido pretende significar o designar objetos de la realidad,

\footnotetext{
${ }^{2}$ Cf. también Martínez Marzoa, 2007: 18-20.
} 
sino que el decir, el lógos, es la forma que tenemos los hablantes de participar y estar implicados en ese acontecer que consiste en que cada cosa sea lo que ella es y que cada cosa se muestre en su irreductibilidad $^{3}$. El punto de partida del griego «es de inmediato la obvia unidad del habérselas siempre ya con las cosas» y somos nosotros, los modernos, los que partimos de la distinción entre sujetos, objetos y enunciados, y los que partimos también de la suposición que el enunciado es una suerte de instrumento que los primeros, los sujetos, utilizamos para referirnos a los objetos determinando así aquello que son ${ }^{4}$. Así pues, del decir la cosa de los griegos hemos pasado al decir enunciados de los modernos, esto es, del ser como mostrarse o aparecer hemos pasado a concebir la verdad como la concordancia entre un enunciado y la cosa por él designada. Y no sólo partimos de la distinción sujeto-objeto, sino que además presuponemos la prioridad de uno de los términos de la relación como el ejemplo de Martínez Marzoa que citamos hace un momento ponía de manifiesto. El mundo moderno es el mundo de la primacía del sujeto: el sujeto se sitúa en el centro del actuar, del representar o del decir y estas actividades siempre producen alguna cosa y se comprenden por relación a algún objeto. Para referirnos al mundo griego sería, en cambio, más propio y adecuado recurrir a nociones como las del acontecer y del participar. Lo que acontece, y de lo que participamos, es un mostrarse aquello que es en su irreductibilidad, lo que supone un punto de partida que nosotros modernos llamaríamos cualitativo.

El modo de comprender y relacionarse los griegos con el tiempo y el espacio ofrece un buen ejemplo de este punto de partida cualitativo. Para nosotros, los modernos, lo por de pronto natural es pensar en el espacio y el tiempo; en la Grecia arcaica y clásica, en cambio, estos sustantivos precedidos de un artículo que los convierte en algo abstracto y universal son simplemente inexistentes ${ }^{5}$. Mientras que nosotros partimos de la idea de un espacio y un tiempo infinitos, como un horizonte que siempre sigue y como un continuo en el que podemos practicar infinitos cortes, el griego, en cambio, piensa siempre en el lugar, en la región o en la distancia, pero como una distancia que «no se percibe en modo alguno como advenida sobre la base de un horizonte que sigue en una y otra dirección, sino que es ella misma lo primero.» (Martínez Marzoa, 1996: 101) Para nosotros, en cambio, el lugar o la distancia son segmentos advenidos sobre esa base infinitamente divisible. Y lo mismo sucede con el tiempo: mientras que nosotros lo imaginamos como una línea en la que se suceden los infinitos puntos del ahora, de cada ahora que ya no es porque se encuentra en el pasado y de cada ahora que será en algún momento del futuro, en el mundo griego, en cambio, «el tiempo no es ahí el horizonte continuo, sino el ritmo del día y la noche y los meses y las estaciones, definido y guardado por los astros» (Martínez

\footnotetext{
${ }^{3}$ Cf. Martínez Marzoa, 2007: 9-11 y 2009: 103.

${ }^{4}$ Este rasgo es importante para comprender la distancia entre nuestros géneros literarios y el decir relevante: «Cuando un griego llama lógos a una tragedia o comedia, o a una oda de Píndaro, no se refiere a que allí haya una secuencia de palabras y oraciones; a lo que en ese caso es llamado lógos pertenecen inseparablemente una melodía, un ritmo, gestos, movimientos. A ningún griego hasta el final de la época clásica, tampoco, pues, a Platón ni a Aristóteles, podría ocurrírsele prever que quizá alguna vez alguien compondría un texto para que otro le pusiese la melodía y el ritmo, quizá incluso un tercero añadiese los movimientos del coro, etcétera.» (Martínez Marzoa, 2006: 19)

${ }^{5}$ Cf. Martínez Marzoa, 1973: 32, así como también: 1990.
} 
Marzoa, 1996: 104) ${ }^{6}$ o el tiempo es también la duración, pero no la duración en el sentido de corte o segmento, sino en el sentido, por ejemplo, del tiempo concreto que nos ha sido concedido a cada uno, esto es, de la distancia irreductible que es la duración de cada vida, del límite que la configura. Así pues, el elemento cualitativo propio del ritmo o la duración conforma el punto de partida griego, todo lo contrario del tiempo y el espacio que concebimos los modernos como algo que siempre andamos midiendo y cuantificando.

El punto de partida griego es, pues, el del 'ser' en el sentido de presencia, de un manifestarse o aparecer la cosa, lo ente, pero de un manifestarse la cosa en su irreductibilidad, es decir, siendo cada cosa lo que ella misma es y no dejándose reducir a nada. La «consistencia irreductible de cada cosa» tiene que ver, como explica Martínez Marzoa en Ser y diálogo, «con eso [...] tan reiteradamente dicho en la Grecia antigua (Tales, Heráclito, Aristóteles) y tan definitorio de lo griego, de que todo y en cada cosa 'hay dioses', todo y cada cosa 'está lleno de dioses'» (Martínez Marzoa, 1996: 24)7. Otra forma griega de expresar la irreductibilidad de cada cosa se encuentra en el brillo y la belleza de la misma: que lo ente tenga ser es aquello que lo hace brillar y que lo hace aparecer en su belleza, dicho de otro modo, la belleza consiste en el brillar de aquello que tiene ser y que se muestra y aparece en su irreductible singularidad. Bello es, pues, el aparecer y mostrarse de cada cosa como lo que ella es ${ }^{8}$. Formulado con un fragmento de Novalis, es decir, con las palabras de un moderno que, sin embargo, se acercan a esta noción de la belleza y del ser como dos aspectos del mismo acontecer, se podría decir que «lo bello es lo visible kat exochen» (Samuel/Mähl/Schulz, 1981: 540), esto es, lo visible en términos absolutos y no relativos. Lo bello no es esta o aquella cosa que posee el atributo de la belleza, o el hacer y producir cosas bellas, lo bello es el mostrarse y ser visible de lo ente en su ser irreductible $\mathrm{y}$ es la forma que tenemos de participar en lo que hay o se $\mathrm{da}^{9}$.

Así pues, decir que el 'dios' habita en cada cosa es un modo de expresar este rasgo tan propio de lo griego en el que confluyen: el estatuto irreductible de cada cosa, su ser, su manifestarse y aparecer mostrando su aspecto propio, su brillo y belleza, y, a la vez, el lado inquietante de una presencia irreductible (Martínez Marzoa, 1996: 126-127) ${ }^{10}$. Por esta razón el llamado decir relevante es inseparable de los dioses. Los dioses necesariamente aparecerán cuando se diga, o se intente decir, ese carácter irreductible de lo que es. Pero este decir, en la medida que se convierte en una tematización de lo irreductible, implicará un vuelco y una pérdida de aquello tematizado en el sentido de que el asunto tratado se vuelve problemático justamente a través de ese decir relevante o excelente que Martínez Marzoa llama también impertinente. La dimensión y las consecuencias de este problemático vuelco se pueden apreciar muy claramente si comparamos tres muestras del decir relevante épico como son las invocaciones a las Musas de los poemas de Homero, Hesíodo y Parménides. Mientras que en

\footnotetext{
${ }^{6}$ Acerca de la obviedad del 'ahora' para los modernos véase: Martínez Marzoa, 2006: 47.

${ }^{7}$ Véase al respecto: Martínez Marzoa 2006: 26-27, 38; 1996: 24-25, 126-127, 130; y 2005: 50-51.

${ }^{8}$ Véase Martínez Marzoa, 1996: 23.

${ }^{9}$ Novalis es ciertamente un moderno, pero un moderno muy cercano a Kant cuya noción de belleza puede considerarse, en un cierto sentido, muy próxima a la griega. Cf. Martínez Marzoa, 2006: 26 y el trabajo al que allí se alude.

${ }^{10}$ Somos nosotros, los modernos, los que partimos de la distinción entre ser y parecer, de la no coincidencia entre ambos términos. Cf. Martínez Marzoa, 1996: 14ss.
} 
el poema homérico la invocación a las divinidades se limita a la breve y conocida fórmula inicial: «Habla, Musa, de aquel hombre astuto que erró largo tiempo después de destruir el alcázar sagrado de Troya [...] Diosa, hija de Zeus, cuéntanos parte de sus andanzas» (Alsina, 1993: 3); en la Teogonía de Hesíodo, en cambio, la invocación a la musa no sólo es notablemente más extensa - de los 10 versos de la Odisea pasamos a los 115 versos del proemio de la Teogonía -, sino que además contiene una alusión a las musas, las divinidades inspiradoras del poema, francamente problemática ya que las musas, algo impertinentes, le comunican al poeta que saben «decir muchas mentiras semejantes a verdades, pero sabemos, cuando lo deseamos, cantar verdades.» (Martín Sánchez/Martín Sánchez, 2001: 30) La posición del poeta inspirado por las musas, como también la del público que le escucha, ha cambiado radicalmente: el rapsoda deja de ser el pasivo receptor de una verdad inspirada por los dioses para convertirse en un oyente a quien se le pide que tenga criterio y que preste atención porque deberá ser capaz de distinguir entre lo falso y lo verdadero ${ }^{11}$. En el poema de Parménides conocido por el título Acerca de la naturaleza, esta sorprendente mención al carácter problemático de la verdad, es decir, a una noción de verdad concebida como el resultado de un acto reflexivo que exige discernir entre aquellas palabras que sólo parecen ser verdaderas y aquellas que lo son, se alarga hasta convertirse en el tema del poema entero. El poema de Parménides describe el difícil y arriesgado viaje en busca de la verdad que emprende el poeta acompañado de una divinidad. La obra de Parménides, escrita en hexámetros como la Odisea, también contiene, al igual que la Teogonía, un proemio algo más extenso en el cual se narra cómo el poeta, impulsado por el deseo de saber, se dirige hacia las puertas que le deberán conducir al camino del saber verdadero y cómo allí, ante esas puertas, se encuentra con la diosa que le saludará y le acompañará. El proemio introduce dos discursos, uno acerca de la verdad y otro sobre las opiniones, en los que se expone la necesidad de distinguir entre un orden imperturbable e inamovible de las cosas, el orden divino, y el mundo de las cambiantes e inciertas opiniones de los mortales. El proemio de Hesíodo ya implicaba o tenía como consecuencia el abandono de la actitud pasiva del poeta, en el poema de Parménides el poeta y su activa búsqueda ocuparán el lugar central del relato épico. El poema justamente empieza cantando el deseo del poeta que, convertido en auriga heroico, emprende el arriesgado viaje en busca del saber verdadero acompañado de una divinidad:

Y la diosa me acogió benévola; tomó en su mano mi mano diestra y así me dirigió la palabra y me decía: "Joven acompañante de aurigas inmortales, llegado con las yeguas que te traen a nuestra casa, salud; que no fue un hado malo quien te impulsó a tomar este camino (pues de cierto que está fuera de lo hollado por hombres) sino ley y justicia. Preciso es que te enteres de todo: tanto del corazón imperturbable de la verdad bien redonda como de las opiniones de mortales en que no cabe creencia verdadera. Aun así, también aprenderás cómo es preciso que las opiniones sean en apariencia, entrando todas a través de todo" (Bernabé, 2003: 156). ${ }^{12}$

\footnotetext{
${ }^{11}$ Cf. Villacañas Berlanga, 1991: 120-124.

${ }^{12}$ Con estos relatos entronca el conocido mito del carro alado que cuenta Platón en su diálogo Fedro (246a-248e): sólo porque el alma ha seguido a las divinidades en su vuelo hacia el reino de lo que verdaderamente es, podrá después, cuando haya caído y se encuentre aprisionada en un cuerpo mortal, conocer, es decir, recordar alguna de las cosas entrevistas en ese mítico viaje.
} 
En resumen: la presencia del deseo está indicando la pérdida de lo obvio, de lo dado. Si hay que querer y buscar la verdad es porque simplemente ya no está presente y a la vista. Cuando se ha empezado a decir que todo está lleno de dioses es porque los dioses han empezado ya a esfumarse (Martínez Marzoa, 1996: 24-25).

¿Qué significa, pues, esta condición huidiza de los dioses en relación al pensamiento platónico? ¿Cómo pasamos del ser como presencia o desocultamiento a ese mundo que - según reza el tópico acerca de Platón - ha quedado escindido en las conocidas esferas de lo sensible y lo ideal? Ya que no es, ni puede ser, el objetivo de este trabajo reconstruir el más que minucioso recorrido exegético de la extensa obra de Martínez Marzoa, me limitaré a indicar aquel momento fundamental en el pensamiento platónico en el cual se descubre una diferencia, justamente esa diferencia que conocemos como 'la teoría de las ideas'. En palabras de Martínez Marzoa:

Platón [...] nunca consideró la teoría de las ideas como una última palabra, sino como el reconocimiento del más grave problema: que, tan pronto como tratamos de ver qué significa ser y, por tanto, qué significa ente, lo ente se escinde en dos planos, de los cuales uno, en esa división, aparece como lo ente y el otro como lo no-ente, sin que por ello deje de tratarse, en todo el negocio, de lo ente (Martínez Marzoa, 1974: 55).

El punto de partida griego es, como dijimos, el de la presencia, el aparecer o el mostrarse cada cosa en su belleza irreductible e incluso inquietante, esto es, en su ser cada cosa ella misma y, por tanto, mostrando un aspecto o figura. Lo ente es lo que tiene ser y su ser es mostrarse teniendo un aspecto, un aspecto que en griego se dice ê̂dos, palabra con la que se designa algo así como presencia o aspecto o figura ${ }^{13}$ y que, por lo tanto, reclama un ver. Es importante recordar que, en este contexto, la palabra 'ver' no designa meramente uno de los sentidos, como si se tratase de la parte de un todo o de un modo de percepción entre otros posibles, sino que el ver menciona de un modo general la relación del hombre al ser y a lo ente - la belleza propia del encontrarse en el ámbito de lo visible, como diría Novalis. Sucede, sin embargo, que una determinada forma de fijarse en eso que es ser, aparecer o ver tiene consecuencias gravísimas ya que produce un vuelco radical en este modo de concebir lo que es ser o presencia. Como dice Martínez Marzoa, se trata de una concentración o de un fijarse «insolente» justamente porque «la insistencia en la presencia es contraria a la presencia misma.» (Martínez Marzoa, 2000: 208)

Lo que está en juego en este insistir insolente es la pregunta por el ser. En un pasaje central de una obra temprana de Martínez Marzoa se encuentra una exposición del pensamiento de Platón que nos ayudará a comprender las enormes consecuencias de este insolente insistir:

Si ser es 'tener una determinación', ente es, por pura gramática, aquello que 'tiene una determinación' (que 'es A' o que 'es B'). Y entonces todo aquello que ordinariamente consideramos ente (a saber: las cosas; en principio: cosa $=$ ente) ¿es verdaderamente?, ¿merece propiamente el nombre de ente?, ¿tiene verdaderamente (como propia) una determinación?, ¿puede decirse con toda propiedad que 'es A' o que 'es B'? Al tropezarnos, por ejemplo, con un caballo, decimos 'esto es un caballo'; pero ¿le pertenece propiamente a 'esto' el 'ser caballo'?; si le perteneciese propiamente, entonces el tal 'esto' no podría dejar de ser algún día caballo; y sabemos que no es así; luego esto propiamente no 'es caballo’; y lo mismo pasará

${ }^{13}$ Cf. Martínez Marzoa, 1996: 22. 
con cualquier determinación referida a cualquier 'esto' concreto. Entonces, nada propiamente es, nada tiene (como propia) una determinación. ¿Realmente nada?; nada, excepto la determinación misma (Martínez Marzoa, 1973: 123).

Ya que, efectivamente, con independencia de todos los caballos concretos, e incluso en un momento en que no hubiera todavía caballo alguno o los caballos hubieran dejado de existir, la determinación 'caballo', esto es, el conjunto de notas que unifica y reúne la noción 'caballo' seguiría teniendo validez. Lo mismo sucedería con el segundo ejemplo que aporta la explicación de Martínez Marzoa:

Más aún: toda cosa es uno, porque es una cosa, y a la vez toda cosa es varios (no uno), porque tiene partes; toda cosa es grande con relación a ciertas cosas y pequeña (no grande) con relación a otras; en suma: toda cosa, por una parte, 'es A' y, por otra, no lo es; en cambio, 'grande' es siempre 'grande' y no pequeño, 'uno' es siempre ‘uno' y no varios. Sólo a la determinación misma le pertenece en propiedad la determinación (Martínez Marzoa, 1973: 124).

De esto podemos concluir que en presencia de lo ente, es decir, en presencia de esta y aquella y aquella otra cosa (el caballo, por ejemplo), lo que verdaderamente está presente es su idea, lo que verdaderamente es y, sobre todo, aquello sin lo cual no habría aspecto o figura o mostrarse cada cosa como aquello que es. En nuestra percepción habitual y cotidiana de la realidad nos parece que estemos ante lo ente, pero al preguntar por lo ente descubrimos que lo ente no aparecería como lo que es si no fuera porque «ya de antemano de algún modo [está] ante nuestra vista la determinación (el eidos)» de ese ente concreto (Martínez Marzoa, 1973: 124). El ámbito de lo dado o de los entes, llamado también el ámbito de lo óntico, remite a algo que está 'más allá' o 'por encima' de lo óntico, a ese otro ámbito que justamente tiene que haber para que podamos comprender lo ente. Debemos, pues, trascender todo lo dado para alcanzar algo que es anterior a todo lo dado y que hace posible experimentar al ente como ente. Este saber ya no es saber de ente o de región particular de lo óntico, sino que es el saber propio de la ontología ${ }^{14}$. Parece, pues, que ante nosotros se encuentre presente la cosa, cuando, en realidad, lo que está propiamente presente es su idea sin la cual la cosa no aparecería o se mostraría con su aspecto o figura determinados. Aquello, pues, que verdaderamente está presente es eîdos, pero al parecer lo hemos olvidado.

¿Qué ha sucedido, pues, al preguntar por el ser? Al «señalar ahora a aquello en lo que consiste que la cosa sea cosa, a aquello en lo que consiste ser» (Martínez Marzoa, 1996: 22), ha sucedido que el ser ha quedado como dividido en, por una parte, la cosa y, por otra, la idea. Y ahí en medio, entre la cosa y la idea, se encuentra el 'es' como el «vínculo de lo uno con lo otro», como «la relación y diferencia de lo uno a lo otro» (Martínez Marzoa, 1996: 23). Al preguntar por el ser se han distinguido dos planos, pero esos dos planos coexisten en la misma cosa y, por eso, la pregunta que necesariamente se habrá de plantear ahora es la pregunta por el vínculo - el 'es' - ya que la diferencia descubierta no es diferencia absoluta sino diferencia en el mismo mostrarse o aparecer de lo ente. Como es sabido, las palabras que nombran este vínculo en el pensamiento platónico son la participación y la mímesis se dice que las cosas participan de las ideas o que las imitan - y éstas serán las palabras cuyo sentido

\footnotetext{
${ }^{14}$ Martínez Marzoa, 1996: 85 y 89.
} 
se intentará captar y definir mediante aquella explicación filosófica que se conoce como la 'teoría de las ideas'.

Para ir acercándonos a la cuestión de la mímesis, nos interesa considerar brevemente qué tipo de saber es el que Platón despliega en sus diálogos y en qué medida los diálogos son una muestra de esos decires relevantes o excelentes. El reconocimiento de esa división en lo ente no implica (o en todo caso no lo implica para una cierta forma de interpretar a Platón) que el saber verdadero sea entonces el saber de la idea, como si ésta fuera algo que se puede llegar a saber o a poseer, sino que implica más bien un tipo de saber cuyo rasgo esencial es el de ser un saber huidizo e inseparable del fracaso de su pretensión. El diálogo platónico es, en primer lugar, ruptura de la onticidad, una ruptura que hará posible el aparecer de lo siempre ya supuesto y que no es aparecer de cosa o ente alguno, sino aparecer de aquello que no siendo ente hace posible el aparecer del ente como mostrando un aspecto o figura, es decir, mostrando una determinación. El diálogo platónico es, pues, como dice Martínez Marzoa, «estrategia de reconocimiento y preservación de la no-onticidad» porque el diálogo intenta hacer comparecer la diferencia de estatuto de cosa e idea «por de pronto en el sentido de la siempre de nuevo producción de un 'ser A es...' que siempre de nuevo se hunde internamente, siendo esa distancia frente a cada posición, frente a cada 'ser A es...', lo que de manera general se mantiene en pie mediante la distancia dialógica.» (Martínez Marzoa, 2005: 94)

Pero además de ruptura, en el diálogo se produce un intento de decir «el carácter mismo del eîdos como tal, su diferencia con respecto a la cosa.» (Martínez Marzoa, 1996: 25) Y esta pretensión es ciertamente problemática porque el desarrollo de la pregunta 'qué es ser...' conduce a un intento de fijar cada determinación a partir de una determinación superior, una determinación superior que técnicamente se llama 'género' en la cual se establece una diferencia que separa la determinación que se quiere fijar de otras determinaciones contenidas en el género, lo cual presupone que este proceder se puede continuar mediante el ascenso por una suerte de escalera de géneros todos ellos susceptibles de ser fijados de la misma manera a partir de géneros superiores ${ }^{15}$. Lo que encontramos entonces es que en cada paso de este itinerario, «en cada momento del intento mismo de fijar algún eîdos, sea éste el que fuere, ciertos eíde están siempre ya supuestos y, como hemos visto, lo están por cuanto el intento de fijación de algún eîdos, cualquiera que sea éste, se rige en todo caso por algo así como criterios referentes a qué es y qué no es un eîdos.» (Martínez Marzoa, 1996: 27) ${ }^{16}$ Dicho mediante una imagen: aquello que guía y orienta el proceso que conduce al saber, lo que guía la ascensión por las sucesivas determinaciones, siempre queda más allá del proceso mismo, opera en cada momento como una suposición imprescindible que ejerce su función de criterio y, sin embargo, nunca la podremos alcanzar mediante el proceder mismo. Esta simultanea imposibilidad y necesidad es, en definitiva, la que determina la estructura del diálogo platónico y del saber dialéctico:

\footnotetext{
${ }^{15}$ Este proceder es conocido como dihaíresis. Cf. Martínez Marzoa, 1996: 25.

${ }^{16}$ Martínez Marzoa cita el ejemplo del pescador de caña que se encuentra en el diálogo El sofista: el ejemplo remite en última instancia a tékhne y, por tanto, a saber, ver y la noción misma de eîdos; así como también a criterios vinculables a nombres como lo uno, la unidad, lo mismo o lo otro. Véase también: Martínez Marzoa, 1996: 94, donde el autor se refiere al mito de la caverna.
} 
[...] es precisamente en aquel continuado fracaso del intento de fijación, en aquel continuado rehusar la tematización, donde hay akríbeia [definición], que sólo en contacto con eso, sólo dentro de ese proceso, las determinaciones tienen akríbeia. Esto parece algo así como que sólo en la siempre continuada ausencia de akríbeia hay, sin embargo, akríbeia. Así es, en el sentido que a continuación intentamos precisar. Cada pauta tematizable, cada norma óntica, resulta ser en último término ambivalente y borrosa; en el sufrir continuadamente esa ambivalencia e imprecisión reside, sin embargo, un 'saber qué'; reside ahí y en ninguna otra parte; no, pues, en el dar la espalda a las normas, ni en el creerse por encima de ellas, ni siquiera en el declararlas 'relativas'; posiciones todas ellas que son falaces porque son otras tantas maneras de eludir la experiencia fenomenológica del hundimiento interno de cada fijación (Martínez Marzoa, 1996: 83-84).

El desarraigo será el duro efecto que producirá la sistemática insolencia del diálogo platónico ya que esta forma del decir relevante no es sino el perseverante esfuerzo por hacer fracasar cualquier intento de responder a la pregunta ‘¿qué es...?' y es, por tanto, el obstinado provocar que estemos «siempre-de-nuevo-en-camino». El saber platónico es un saber «que nunca conduce a morada» (Martínez Marzoa, 1996: 129) ${ }^{17}$. Poco tiene que ver esta experiencia con «lo que se considera corrientemente platonismo, la 'teoría de las ideas'», es decir, con «la tesis de un mundo inteligible separado del mundo sensible en el que vive el alma exilada y añorante del primero» como dice Patricio Peñalver en su ensayo sobre «la forma del saber» en Platón ${ }^{18}$. El ềdos no es otra cosa que el intento de tematizar el 'ser', pero un intento que al llevarse a cabo descubre y experimenta que el ềdos es aquello que siempre acabará escapando a toda tematización. Como dice Martínez Marzoa comentando el itinerario descrito en el mito de la caverna: «el viaje no se hace por mor de lo de allá, sino por mor de la diferencia misma,» ya que «aquello, lo de fuera, no es jamás el asunto, lo que hay, lo ente. Contundentemente, el episodio último y definitivo de la historia es el retorno.» (Martínez Marzoa, 1996: 93-94) Pero un retorno que procede de un lugar que nunca se habrá llegado a conocer. Esta es, pues, la experiencia trágica e inquietante que el diálogo platónico escenifica ${ }^{19}$.

Con el recorrido hecho hasta ahora ya podemos dirigir nuestra atención hacia el tramo final del diálogo platónico la República, el libro X, en el cual se encuentra el famoso rechazo de la poesía mimética, un rechazo que se presenta como la culminación de una «desavenencia entre la filosofía y la poesía [que] viene de antiguo» (607b) y que, usando los términos de Martínez Marzoa, se puede describir como el conflicto entre dos modos del decir relevante que justamente se constituyen como dos modos diferenciados entre sí a través del rechazo mismo en el cual, sin embargo, se pone al mismo tiempo de manifiesto la coincidencia de ambas pretensiones. Cuando Platón afirma que los poetas deben ser expulsados de la ciudad ideal es plenamente consciente de la gravedad de su propuesta y, por este motivo, las razones que pueda aducir para fundamentar tan drástica conclusión deberán ser

\footnotetext{
${ }^{17}$ Martínez Marzoa explica este efecto desarraigante mediante una interpretación del diálogo El banquete y la figura del daímon.

${ }^{18}$ Cf. Peñalver, 1990: 23. Menciono el texto de Patricio Peñalver porque propone una lectura de Platón en cierto modo análoga a la de Martínez Marzoa aunque la suya es de inspiración derridiana. Ambas exposiciones de Platón giran alrededor de esa paradoja dramática e irresoluble a la que Martínez Marzoa se refiere como aquel triunfo relativo que surge del continuado fracaso de la fijación del ê̂dos y Patricio Peñalver llama la «autodesconstrucción del texto platónico», es decir, la constatación de que aquello «que hace posible el pensamiento se sustrae al saber» (Peñalver, 1990: 24-25).

${ }^{19}$ La imposibilidad de decir el ềdos, ya que se dice siempre lo óntico, implica para el diálogo la necesidad de recurrir a una serie de estrategias de distanciamiento para hacer acontecer aquello que no se puede decir. Cf. Martínez Marzoa, 1996: 59.
} 
especialmente convincentes. Pero la minuciosa argumentación que Platón despliega en el libro X de la República, en realidad, añade todavía más desconcierto al que seguramente ya habrá producido su convicción de que no hay lugar para la poesía en la ciudad ideal. La argumentación platónica recorre una doble senda que, haciendo uso de términos modernos, podríamos describir del siguiente modo: el primer tramo de la argumentación posee un carácter más epistemológico ya que en él se dirime la cuestión del contenido de verdad de la poesía; el segundo tramo, en cambio, es de índole más psicológica puesto que reflexiona acerca de los efectos de la poesía en el alma del espectador. Las conclusiones son conocidas: mientras que la argumentación epistemológica demuestra que la poesía imitativa se aleja doblemente de la verdad, el argumento psicológico consiste en demostrar que la poesía produce sus efectos a través de la identificación emocional y que, por lo tanto, alimenta la parte irracional del alma que se deja seducir, provocar e incitar con más facilidad. Parece, pues, que Sócrates tiene dos buenas razones para mantener la poesía alejada de la vida de la ciudad ideal ${ }^{20}$.

Aunque en ambas partes de la argumentación la noción de mímesis juega un papel central, primero concebida como imitación respecto de la idea y luego concebida como identificación emocional, nos interesa aquí especialmente la primera parte de la argumentación ya que la cuestión que se está dirimiendo en este conflicto entre decires relevantes es justamente la del saber o la verdad propios del decir de «los poetas trágicos y todos los que hacen imitaciones». El largo recorrido argumentativo que deberá justificar la expulsión de los poetas empieza necesariamente con la siguiente pregunta socrática: «¿Podrías decirme en líneas generales qué es la imitación?»(595c). Para determinar qué es la imitación, el diálogo propone un doble camino. En primer lugar utiliza la hábil analogía entre la pintura y la poesía, así como la comparación entre tres tipos distintos de artesanos. El punto de partida del recorrido platónico es el artesano que hace camas o mesas. Para realizar las múltiples camas o mesas el carpintero, dice Platón, deberá elevar la mirada hacia la idea de cama o de mesa que, a diferencia de las múltiples y variadas camas o mesas sensibles, es única. El artesano que ha hecho esta idea necesariamente única de cama o mesa, es decir, el artesano que ha producido la naturaleza o lo que es en sí mismo cada uno de esos entes particulares, recibe el nombre de Dios y lo que él produce, la idea, ocupará el lugar más elevado en la escala del ser, mientras que las camas o las mesas que usamos para dormir o comer poseerán un grado inferior de ser en la medida que son solamente imitaciones de la idea. Pero Dios y el carpintero no agotan todas las posibilidades de producción artesana ya que existe un tercer tipo de artesano «hábil y sorprendente» que es capaz de hacerlo todo: «es capaz, no sólo de hacer todos los muebles, sino de producir todas las plantas, todos los animales y a él mismo; y además de éstos, fabrica la tierra y el cielo, los dioses y cuanto hay en el cielo y en el Hades bajo tierra.» (596c) Este «maestro maravilloso» lo hace efectivamente todo, pero lo hace sólo en apariencia ya que el modo de proceder de este artesano consiste en «tomar un espejo y hacerlo girar hacia todos lados» y, de este modo, prosigue Sócrates, «pronto harás el sol y lo que hay

\footnotetext{
${ }^{20} \mathrm{La}$ argumentación que llamamos psicológica enlaza directamente con lo dicho en los libros II y III de la República, aunque presupone también la concepción del alma expuesta en el libro IX; la argumentación que llamamos epistemológica es inseparable de la 'teoría de las ideas' expuesta en el libro VII. Sobre esta cuestión véase Halliwell, 2005.
} 
en el cielo, pronto la tierra, pronto a ti mismo y a todos los animales, plantas y artefactos, y todas las cosas de que acabo de hablar.» (596d-e) Este tercer artesano es como el pintor cuya producción se limita a ser mera imagen que reproduce aquellos objetos que llamamos reales pero que, en realidad, ya son ellos mismos mera imitación de la idea. Así pues, concluye el diálogo, la imagen del pintor no es sino copia de la copia, débil y lejano reflejo de lo que verdaderamente es. Como subraya Martínez Marzoa, el saber de este artesano, a través del cual se explica indirectamente en qué consiste el saber de los poetas imitativos, es un saber extraño y paradójico ya que es «un saber de todo o quizá de nada» (Martínez Marzoa, 2000: 202) puesto que oscila entre la pretensión de abarcar la realidad entera y el resultado poco honroso de no saber nada concreto, un resultado ciertamente pobre si lo comparamos, no sólo con la magnitud excesiva del objetivo que se había propuesto, sino también con los resultados de cualquiera de los saberes particulares: «el arte mimético está sin duda lejos de la verdad, según parece; y por eso produce todas las cosas pero toca apenas un poco de cada una, y este poco es una imagen.» (598b) La cuestión que habrá que pensar será, pues, la siguiente: en qué consiste «ese poco» y qué es «una imagen» y habrá que seguir pensándolo ya que el diálogo dice al respecto cosas poco convincentes: quien hace una imagen no pretendía hacerlo todo, como insinúa Sócrates, sino hacer justamente una imagen. Por eso tiene poco sentido juzgar la imagen comparándola con aquello que se supone que es el objeto de la representación: «¿Piensas entonces que, si alguien fuera capaz de crear tanto el objeto que es imitado como su imagen, pondría su celo en entregarse a la artesanía de las imágenes, y que en su vida antepondría esto a lo demás, como siendo lo mejor?» (599a-b)

La segunda determinación de la mímesis también se articula mediante una comparación. Se comparan ahora tres posibles relaciones con un objeto: «Con respecto a cada cosa» dice Sócrates «hay tres artes: el del que la usa, el del que la hace y el del que la imita» y añade a continuación que el usuario es el «verdadero entendido», pues «es quien usa el objeto, [...] el que posee el conocimiento», y, por ello, también será el usuario el encargado de dar instrucciones al fabricante para que éste pueda tener una «opinión correcta en lo tocante a la bondad o maldad» de la cosa: «Es de toda necesidad, por consiguiente, que el que usa una cosa sea el más experimentado en ella, y que pueda informar al fabricante de los efectos buenos o malos que se producen en su uso» (601d-e). La valoración socrática concuerda, pues, con la noción del saber como aquel habérselas con las cosas que es pericia o destreza: Sócrates atribuye el verdadero saber al usuario y no al artesano en cuya actividad ciertamente se produce ya algo así como distancia y tematización. En cualquier caso, usuario y artesano poseen todavía algún tipo de saber válido con sus respectivos grados de consistencia. Y al igual que en la analogía anterior, también en el contexto de esta clasificación de los posibles modos de relacionarse con el objeto se nos presenta finalmente un tercer tipo que encarna la figura del dicente mimético cuyo saber se encuentra en el escalón más bajo de la valoración de los distintos modos de conocimiento. El tipo en cuestión es el productor de imágenes con las que se limita a representar las cosas sin tener «conocimiento ni opinión recta de las cosas que imita, en cuanto a su bondad o maldad» e insiste Sócrates un poco más adelante: «el imitador no conoce nada digno de mención en lo tocante a aquello que imita» (602b). Sus imágenes, sin embargo, poseen una naturaleza realmente paradójica, ya que a 
pesar de haber sido producidas sin «conocimiento ni opinión recta de las cosas que imita» (602a) ejercen sobre el espectador un efecto sumamente seductor y convincente. De ahí justamente la peligrosidad pública del imitador poético, ya que con sus imágenes no sólo produce la engañosa apariencia de saber, sino que también alimenta las pasiones más irracionales incluso en las almas más sensatas y precavidas. La conclusión última de la meticulosa argumentación es conocida y decepcionante:

$[\ldots]$ debemos $[\ldots]$ convenir con ellos [los que alaban a Homero] en que Homero es el más grande poeta y el primero de los trágicos, pero hay que saber también que, en cuanto a poesía, sólo deben admitirse en nuestro Estado los himnos a los dioses y las alabanzas a los hombres buenos. Si en cambio recibes a la Musa dulzona, sea en versos líricos o épicos, el placer y el dolor reinarán en tu Estado en lugar de la ley y de la razón que la comunidad juzgue siempre la mejor (607a).

Varios son, efectivamente, los motivos por los que este último libro de la República platónica puede producir sorpresa y desconcierto en el lector actual. El último pasaje citado ofrece una buena prueba de la justificada extrañeza que nos puede provocar la posición socrática a causa de su carácter puritano y censurador ante un decir que es considerado nocivo e irracional por el hecho de despertar emociones intensas e incontenibles en el espectador. Pero quizás sea la argumentación misma la que nos suscite más reparos, no sólo por las posibles inconsistencias o por la sospechosa y excesiva claridad de las analogías empleadas, sino por el abismal contraste que surge entre las conclusiones a las que llega y los fundamentos teóricos sobre los cuales reposan esas conclusiones, ya que el entero desarrollo argumental del libro X es del todo incomprensible sin aquello que ha sido expuesto en los libros VII y IX de la República, es decir, sin la llamada teoría de las ideas y sin la concepción del alma de Platón. La pregunta deviene inevitable: cómo es posible que desarrollos teóricos con un valor explicativo tan enorme e incuestionable como son la teoría de las ideas o la teoría del alma, capaces de revelar aspectos fundamentales del carácter trágico, ambiguo y problemático del saber, o de descubrir la estructura política de lo anímico y, en consecuencia, la importancia de la educación y el cuidado del alma al construir la ciudad ideal, cómo es posible, pues, que tan iluminadores y matizados desarrollos teóricos se conviertan al final del diálogo en el fundamento de unas conclusiones tan simples, unívocas y escasamente sutiles, es más, se conviertan en el fundamento de una posición respecto del fenómeno poético tan insensible, puritana y dogmática ${ }^{21}$. El libro $\mathrm{X}$ de la República es, en cualquier caso, un texto de difícil digestión, y lo es especialmente para el gremio de los estudiosos de la literatura que debemos contemplar cómo un autor clásico y fundamental de la historia de la crítica literaria llega a la conclusión de que es del todo necesario expulsar a los poetas de la ciudad ideal.

Los intentos de explicación y comprensión del texto optan a menudo por la contextualización histórica recordando que Platón vivió en un momento de transición en el cual se estaba produciendo el paso de una tradición oral a otra basada en la escritura y, por lo tanto, en el momento delicado y crucial en el que se gestaba un cambio radical de modelo educativo: la poesía, que durante siglos había

\footnotetext{
${ }^{21}$ Sirva de ejemplo el estudio de Baldine Saint Girons sobre lo sublime en el cual se encuentra un hermoso ejemplo del potencial explicativo y crítico del mito de la caverna platónico. Cf. Saint Girons, 2008: 27-44.
} 
sido el instrumento de transmisión de los saberes vinculantes en un mundo sin apenas texto y dominado por los valores aristocráticos, estaba condenada a perder su posición hegemónica en la paideía a causa de la gradual introducción de la escritura y de los nuevos valores vinculados a la vida de la polis. Y de ahí la vehemencia de Platón: rechazar la poesía no era rechazar una actividad íntima y privada, sino pronunciarse contra un modelo educativo basado en la memoria y la identificación emocional ${ }^{22}$.

El hecho de que Platón se encuentre en un momento histórico de transición contribuye seguramente a complicar su comprensión. El mismo Martínez Marzoa comprende el pensamiento platónico como un protagonista decisivo del vuelco que se está produciendo e incluso considera que el rotundo rechazo de la mímesis supone un episodio especialmente relevante del vuelco en cuestión. Importancia, por cierto, que viene justamente subrayada por el hecho de encontrarse en el último tramo de la República, un tramo del diálogo que funciona como recapitulación final de la extensa y fundamental obra de Platón. La paradoja o ambigüedad central de Platón consiste en presentar como un decir mimético esa «antigua sabiduría» que empieza con Homero y que llega hasta Protágoras y, a la vez, formular un rechazo o denuncia respecto de esta forma de saber mediante un decir que es él mismo mimético. Con este rechazo o esta desconfianza hacia esta forma de saber se está, pues, esbozando un ámbito del decir relevante que siendo él mismo mímesis lo es en un sentido particular y distinto de esos otros saberes tradicionales que arrancan con el poema homérico y llegan hasta el saber de los sofistas. El sophós, es decir, el sabio en el sentido griego ya comentado del experto o entendido en algo, siempre posee un saber acerca de algún tipo determinado de cosas que se despliega y realiza, por ejemplo, como saber del navegante, del carpintero, del médico, del agricultor o de cualquier otro oficio particular que en cada caso conduce a algo concreto como podría ser, siguiendo la serie de los ejemplos propuestos, a puerto, a utensilio, a curación o a cosecha. Lo que plantea el libro X de la República es la cuestión de un saber-hacer que lo es con referencia a cualquier cosa - como el saber del que se pasea por el mundo sujetando un espejo o del que pinta lo que otros producen y utilizan $-\mathrm{y}$ que, en ese pasaje final del diálogo, recibe el nombre de mímesis para ser convertido en objeto de sospecha y de rechazo. Lo que se rechaza, sin embargo, no es pura y simplemente este decir sin ámbito determinado de aplicación, lo cual sería francamente extraño ya que el diálogo platónico puede justamente ser considerado un ejemplo de sostenido decir mimético, sino una muy concreta forma de decir mimético que, en cierta manera, comparte con el diálogo platónico la pretensión de totalidad. Y es exactamente en el modo de pretender la totalidad donde radica la diferencia entre los dos modos de la imitación. El decir platónico se distingue del otro decir mimético porque este último concibe la falta de determinación de campo como la totalidad de lo ente o como la suma de saberes concretos que conducen a sus respectivos resultados igualmente concretos y palpables, contantes y sonantes, como haría cualquier saber acerca de cosas o entes. Lo que se rechaza es, pues, un saber que, a pesar de prescindir de toda especificación de un campo concreto - como, según Platón, hacen los sofistas a

\footnotetext{
${ }^{22}$ Sobre este aspecto insisten especialmente los trabajos de Giovanni Reale y Eric Havelock entre otros. El libro X de la República también se interpreta como la temprana e indirecta delimitación de aquello que nosotros conocemos como el ámbito de lo estético o de la representación. Cf. Galí, 1999.
} 
quienes considera los últimos herederos de la tradición homérica -, sigue siendo un saber del cual se espera que capacite «para producirse ahora como sabio en esto y luego como sabio en aquello sin serlo ni precisamente en esto ni precisamente en aquello. Se trata de la concepción de aquel saber que, de todos modos, lo es de las cosas, de lo ente, como un saber positivo y que conduce a algún resultado, de manera similar a como el saber del marinero conduce efectivamente a puerto; por eso es lícito preguntar a Homero qué póleis ha hecho efectivamente mejores.» (Martínez Marzoa, 1996: 111) ${ }^{23} \mathrm{El}$ saber sin especificación de ámbito que Platón propone será, en cambio, el saber de la distancia, de la diferencia y de la ruptura con todo saber de cosas o entes y, por lo tanto, un decir mimético o relevante que haga emerger y comparecer el juego que ya siempre se está jugando, esto es, un saber de aquello en lo que siempre ya se está, pero que ya siempre ha quedado atrás por su naturaleza de saber ya siempre supuesto; en resumen, un saber que no es saber de suma o de conjunto de entes, sino saber de aquello en lo que hay presencia, en lo que hay mostrase y determinación y que, por ello, se sustrae a la mirada. Dicho con las palabras del fragmento de Novalis que he citado más arriba: la verdadera mímesis no consistiría en ver cosas, sino la visibilidad, el ser visible mismo en el que las cosas se muestran y aparecen. Y lo bello sería entonces lograr que la visibilidad misma compareciera. O dicho todavía de otro modo, el decir mimético platónico sería un saber acerca de eso que llamamos sentido, esto es, el saber ambiguo y escurridizo «de todo o nada» o ese «saber a secas» en el que las cosas, sin embargo, se dan. El rechazo de la sofística y de los saberes antiguos se justifica, pues, por el hecho de que éstos se conciben según el modelo de los saberes de cosas, de los saberes particulares, mientras que el saber al que aspira el diálogo platónico es un saber que, en realidad, no puede ni ser dicho, ya que, según afirma Martínez Marzoa, el lenguaje siempre dice lo ente, mientras que el diálogo platónico adquiere su consistencia propia en la medida que logra ser el permanente intento de ruptura y separación respecto de lo ente para descubrir lo que está implícito y supuesto en todo mostrarse y aparecer. Esta es la terrible paradoja a la que se enfrenta el verdadero decir mimético y, por esta razón, el diálogo finalmente logrará ser un decir relevante o excelente cuando en él simplemente acontezca ese otro saber que no puede ser en ningún caso saber de lo ente ${ }^{24}$.

De nuevo una cita de un pensador del romanticismo alemán - justamente de estos pensadores con los que el llamado paradigma de la imitación termina y que quizás por ello estén creando las condiciones para pensarla con más propiedad - nos podrá ayudar a comprender esta cuestión. El rechazo y superación del modelo mimético en la estética del romanticismo alemán es inseparable de su nueva manera de concebir del lenguaje: el arte deja de ser explicado como práctica mimética porque es el lenguaje mismo el que ya no se entiende desde el modelo de la imitación, la copia o la representación. Para los románticos, el lenguaje ya no es el instrumento mediante el cual se imita o representa una realidad cuya existencia vendría ya dada y sería previa al momento de su designación, sino que el lenguaje mismo es pensado como acto creativo y, sobre todo, como un acto de donación de sentido. Con el lenguaje surge un mundo - «una delicada medida y compendio de las cosas» (Caner-

\footnotetext{
${ }^{23}$ Véase también Martínez Marzoa, 1996: 135-136.

${ }^{24}$ Martínez Marzoa, 2000: 204.
} 
Liese, 2007: 269) dirá Novalis en su Monólogo - que luego, secundariamente, será designado por el lenguaje en el sentido de un mero signo. Dicho con palabras de Martínez Marzoa: el lenguaje poético sería un decir relevante en la medida que en él se hace presente el juego que ya siempre se está jugando, un juego que es inseparable del lenguaje mismo. En el decir poético o mimético el lenguaje aparecería como aquello que funda sentido, esto es, como aquello en lo cual acontece el mostrarse y aparecer las cosas con su aspecto determinado. La palabra es el material del que parte y con el que trabaja el decir poético, la palabra, sin embargo, es un material extremadamente peculiar ya que sólo es ente en un sentido secundario y derivado: ya que la palabra será signo y sólo podrá ser signo - esto es: ente porque es en ella y por ella que se da la visibilidad en general. El decir poético es el esfuerzo de ruptura de esa reducción óntica del lenguaje que no alcanza a ver más allá del signo, es decir, de la reducción del lenguaje a mero instrumento de la designación o la expresión, para hacer aparecer la dimensión ontológica de la palabra. En el curso sobre arte y literatura que pronunció A.W. Schlegel en Berlín en el año 1801 se encuentra la siguiente formulación de este revolucionario descubrimiento:

El medio de la poesía es, empero, cabalmente el mismo por cuyo medio logra el espíritu humano el conocimiento y se apodera, combinándolas y expresándolas, de sus ideas: la lengua. Tampoco está, por tanto, ligada a los objetos, sino que se crea los suyos propios; es la más extensa de todas las artes, y, por así decirlo, el espíritu universal presente en todas ellas. [...] La lengua no es producto alguno de la naturaleza, sino impronta del espíritu humano, que coloca en ella el origen y la afinidad de sus figuraciones y todo el mecanismo de sus operaciones. En la poesía, por tanto, se forma una vez más lo ya formado; y la ductilidad de su organismo es tan ilimitada como la capacidad del espíritu de regresar a sí mismo por medio de reflexiones elevadas cada vez a mayor potencia (Arnaldo, 1987: 121-122) ${ }^{25}$.

En la obra de arte se produciría, pues, una suerte de distanciamiento reflexivo respecto del lenguaje en el seno mismo del lenguaje o, dicho con otras palabras, el sentido que acontece en y por la palabra como aquel mostrar y hacer aparecer lo ente, deviene tema de la poesía sin que por ello sea literalmente dicho: mediante la paradójica forma de un distanciamiento interno, el lenguaje poético consigue que aquello que se retrae y oculta, el lenguaje mismo, aparezca. La poesía o el arte de la palabra será, pues, un intento de que el decir mismo acontezca y se muestre ${ }^{26}$.

Existe una obra de Perejaume del año 1984, «Postaler» («Guardapostales») ${ }^{27}$, que parece directamente inspirada por una imagen central del libro $\mathrm{X}$ de la República y que quizás pueda ayudarnos a comprender y seguir pensando el sentido de la noción de mímesis. En este extenso tramo del diálogo platónico dedicado a clarificar qué es la mímesis y, al mismo tiempo, a justificar la

${ }^{25}$ La imagen de la potenciación especular ya se encuentra en el fragmento 116 del Athenäum en el cual Friedrich Schlegel expone de manera compacta y programática la poética del primer Romanticismo alemán. Cf. Pajerols, 2009: 81-82.

${ }^{26}$ Cf. Martínez Marzoa, 1996: 58-59 donde se afirma que «se trata, pues, de que aquel decir para el cual eso que llamamos 'el lenguaje' o incluso ‘el decir' es inadecuado por principio; pues el decir dice cosas, o sea, entes, no en qué consiste ser.» Desde el punto de vista romántico seguramente sea problemática la afirmación de Martínez Marzoa según la cual el lenguaje siempre dice cosas, siempre dice lo ente. La generación romántica descubre justamente la dimensión ontológica del lenguaje, una dimensión que, ciertamente, no puede ser dicha en el sentido de que no puede ser recogida en un enunciado. Topamos aquí, sin embargo, con una cuestión que trasciende ampliamente los límites del ensayo: la cuestión de si estos intentos de forzar los límites del modelo sujeto-objeto permanecen o no dentro del paradigma cuestionado, es decir, la pregunta por la posibilidad de trascender el paradigma, y, sobre todo, la pregunta si es o no es deseable hacerlo. Un texto fundamental al respecto sería el último ensayo de la obra De camino al habla en el que Heidegger comenta el Monólogo de Novalis.

${ }^{27}$ Cf. Perejaume, 1999: 130-131. 
necesidad del rechazo de cierto discurso mimético, Platón utiliza la imagen clásica, y ya citada, del espejo. Con ella intenta explicar el modo peculiar de proceder de ese «maestro maravilloso" capaz de hacerlo todo: sólo hay que «tomar un espejo» dice Sócrates «y hacerlo girar hacia todos lados» (596d). Esto es casi literalmente lo que hace «Postaler», una obra que, como muchas otras obras de Perejaume, no sólo es el resultado de una mezcla de géneros que la hace difícilmente clasificable, sino que además responde al intento de ser obra en un grado mínimo. El «Postaler» es, en primer lugar, la fotografía de un ready-made, ya que la imagen nos muestra justamente el guardapostales que da nombre a la obra. Se trata, sin embargo, de una peculiar versión del género de los objetos encontrados. El guardapostales que muestra la fotografía, como suele suceder con el ready-made, se encuentra en un lugar inusual: mientras que lo habitual es encontrar este artilugio metálico en la recepción de un hotel o en las tiendas de recuerdos para los turistas, el guardapostales de Perejaume se yergue solitario en medio de un paisaje forestal. Además hay otra importante modificación respecto de las expectativas que pueda despertar este objeto estrechamente vinculado al comercio turístico. Como es sabido, el objetivo del guardapostales es exhibir postales para su venta y, a tal efecto, su estructura cilíndrica y giratoria dispone de numerosos compartimientos ordenados en hileras verticales y provistos de unas guías que permiten colocar en su interior los pequeños fajos de postales para que el turista pueda sacar con la máxima comodidad las imágenes escogidas. En el «Postaler» de Perejaume, en cambio, los espacios destinados a las postales están ocupados por pequeños espejos rectangulares que tienen el tamaño de una postal y que producen el sorprendente efecto de reproducir sobre el conjunto de sus superficies alineadas el entero entorno forestal en el cual ha sido plantado el guardapostales.

La referencia del «Postaler» a la cuestión de la mímesis es, pues, doble: en primer lugar, porque el ready-made puede entenderse como un ejemplo de imitación perfecta en la medida en que el objeto expuesto en el museo o la sala de exposiciones (en nuestro caso el bosque) es exactamente igual al objeto citado o representado por él; y, en segundo lugar, porque el «Postaler» de Perejaume es capaz de hacer lo mismo que aquel maravilloso artesano platónico que sabe producir la realidad que le rodea con sólo ir girando su espejo. Para comprender mejor el asunto que aquí nos ocupa será, pues, necesario preguntarse qué hace el «Postaler» de Perejaume, es decir, qué sentido puede tener el mostrarnos una imagen o representación que contiene a su vez una alusión a ese tipo concreto de imagen o representación que es la postal. El objeto escogido por el artista posee una enorme carga significativa. El guardapostales es una inequívoca alusión a esa actividad tan característica de nuestros tiempos como es el turismo y es asimismo una alusión a su capacidad de reducir los más diversos lugares a un escaso número de estampas o imágenes que nos sirven para identificar los objetivos del viaje antes de partir, para definir los itinerarios que vamos a seguir o para llevarnos un recuerdo a casa cuando regresamos a nuestra vida cotidiana. Mediante esta referencia a la actividad turística, el «Postaler» trata una cuestión muy presente en toda la obra de Perejaume: el tema del exceso de obra en el sentido de un exceso de representación que produce el inquietante efecto de ocultar y reducir la realidad. Cuando la superficie del mundo acaba recubierta de imágenes, de obra humana, sucede entonces que sólo sabemos ver y reconocer aquello que ya hemos visto con anterioridad, esto es, nuestras 
representaciones de la realidad no dejan intersticio alguno por el cual ver algo distinto y, sobre todo, ver algo que no sea siempre representación del sujeto mismo. El «Postaler» de Perejaume desplaza el emblemático artilugio a un espacio inusual y, sin embargo, tan emblemático como el guardapostales mismo ya que el hayedo al cual ha sido trasladado el ready-made constituye, desde el punto de vista de los paisajes catalanes, un espacio íntimamente asociado a la promoción turística, a la tarea de protección del medio ambiente e incluso a una popular escuela de la tradición pictórica catalana ${ }^{28}$. Un espacio natural, pues, que resulta difícil de reconocer y de percibir porque se ha convertido él mismo en una suerte de inmensa sala de exposiciones en la que un paisaje se exhibe a sí mismo. La labor del artista no podrá ser entonces añadir una más a las imágenes ya existentes y, por esta razón, intentará evitar hacer una cosa que ya está hecha - como diría Sócrates. Aquello que el «Postaler» intenta es más bien provocar una ruptura y una distancia a través de la cual se muestre y se haga aparecer el juego que ya siempre se está jugando: el de un determinado modo de representación que miniaturiza el mundo. El «Postaler» se puede comprender, pues, como un decir relevante o mimético que no reproduce ni imita lo ente, sino que apunta al modo de mostrarse de lo ente en el juego mismo de los excesos de la representación. Porque lo siempre ya supuesto es precisamente la postal. Para ello el «Postaler» hace surgir un mundo a través de la relación recíproca de hayedo y representación especular. Pero el mundo del guardapostales que nos muestra la obra de arte llamada «Postaler» ya no es la simple repetición de las imágenes tópicas de la postal, ya que el reflejo fragmentado y minimalista de las series de espejos que ocupan el lugar de las postales ofrecen una visión del hayedo que multiplica y matiza la mirada en vez de fijarla y petrificarla. Aquello que la postal identificaba y hacía inmediatamente reconocible, aparece en el reflejo especular del «Postaler» descompuesto en inabarcables detalles que una única mirada no logra captar y dominar. A pesar de que el espejo sigua imitando la realidad con la fiel exactitud que le caracteriza, el efecto último de esta exactitud es la extrañeza y el desconcierto.

Tiene, pues, su lógica que el artista y su producir desaparezcan máximamente de la obra cuando ésta surge de la inquietud e insatisfacción que provoca la presencia excesiva de obras: con el readymade se reduce a la mínima expresión la obra en tanto que objeto hecho o producido por el artista. Su labor se limita entonces a la acción escasamente artística de sustituir postales por espejos y de desplazar el guardapostales. De ahí la importancia de una segunda imagen que acompaña y completa el «Postaler» en la cual se puede ver a «Perejaume transportando el guardapostales»: sobre un horizonte montañoso, aunque muy bajo y discreto ya que el cielo ocupa casi la totalidad del fondo de la imagen, vemos al artista andando con el guardapostales vacío sobre un hombro y cargando una mochila en la cual suponemos que habrá guardado el juego de espejos para ponerlos en el lugar previsto cuando haya

\footnotetext{
${ }^{28}$ Cf. Perejaume, 1995. El último capítulo de El paisatge és rodó, que lleva por título «L'oli d’Olot», me parece una excelente muestra de la poética de Perejaume. De la misma época es la obra «Pintura d'Olot que ha tornat la seva imatge a Olot» («Pintura de Olot que ha devuelto su imagen a Olot», 1993), obra que pudo verse en la exposición retrospectiva que se celebró en Barcelona entre octubre de 2011 y febrero de 2012 con el significativo título: «Ai Perejaume, si veies la munió d'obres que t’envolten, no en faries cap de nova!» («Ay Perejaume, si vieras la acumulación de obras que te rodea, no harías ninguna más!»). La obra mencionada se puede ver en: Perejaume, 2011: 48.
} 
encontrado otro emplazamiento adecuado para plantar el guardapostales y, de este modo, convertir las peculiares postales en el fiel y, a la vez, extraño reflejo del lugar.

Así pues, la obra «Postaler» puede entenderse como el ambiguo esfuerzo por mostrar el juego de la representación y, a la vez, por provocar una ruptura en el mismo. Y todo esto, sin embargo, se realiza sin abandonar el juego mismo de la representación. Considero que es una muestra inequívoca de la inteligencia de esta obra el querer expresar un comprensible malestar ante la sobreabundancia de representaciones que aplanan y ocultan la realidad sin creer, sin embargo, que ahí detrás, o que más allá de todas las imágenes y las representaciones, se pueda encontrar la verdadera y auténtica realidad. El juego que estamos jugando es el de la representación, esto no significa que el juego nos impida desarrollar formas de ruptura del mismo, la ruptura, sin embargo, no abandonará el modelo de la reflexión. El «Postaler» efectivamente recuerda la estructura de numerosas imágenes románticas en las que se tematizan la mirada y la representación mediante la célebre repetición reflexiva: quien mira la imagen ve en ella a alguien de espaldas que está haciendo exactamente lo mismo que el espectador - mirar - y que con su mirar construye una realidad representada. Del mismo modo, la imagen de Perejaume habla de imágenes que imitan o reflejan la realidad, la imagen, sin embargo, incluye la posibilidad de llegar a saber algo del juego que se está jugando y a producir una bella y significativa distancia respecto del mismo.

Para terminar citaré un brevísimo texto del mismo Perejaume que propone otra certera imagen de este decir relevante. Se trata nuevamente de la descripción de un hacer que casi no produce obra, ya que se trata más bien del montaje de un pequeño artilugio casero que, significativamente, ha sido realizado por dos amigos. Ambos detalles - el tratarse de un artefacto con escaso valor estético y el que sean dos personas los protagonistas del relato - nos parecen importantes por lo que hemos visto hasta aquí ya que contribuyen a distanciarnos del modelo sujeto-objeto, forzándolo hasta el límite, aunque sea sin abandonarlo. El texto de Perejaume narra un hacer gracias al cual se produce un iluminarse a sí misma la naturaleza, un aparecer de lo que ya siempre está ahí surgiendo y brotando pero que ha precisado de esta mínima intervención para salir a la luz. El texto de Perejaume que lleva por título «L'escriptura» («La escritura») en el cual se narra este intento de leer la naturaleza dice así:

En un rial de muntanya, i amb l'ajut d'un amic, hem instal·lat un mecanisme, a través del qual la pressió de l'aigua genera corrent elèctric. / Tot el corrent va connectat a una bombeta que il·lumina el mateix salt d'aigua que genera la llum. De nits, l'aigua brilla enmig del bosc i, segons com sigui el doll, la llum també creix o decreix d'intensitat (Perejaume, 2003: 147) ${ }^{29}$.

\footnotetext{
${ }^{29}$ «En un torrente de montaña y con la ayuda de un amigo hemos instalado un mecanismo mediante el cual la presión del agua genera electricidad. La corriente se encuentra conectada a una bombilla que ilumina el mismo salto de agua que genera la luz. Por la noche, el agua brilla en medio del bosque y según sea el chorro también aumenta o disminuye la intensidad de luz».
} 


\section{Bibliografía}

AlsinA, José, ed. (1993): HoMERo, Odisea. Introducción y notas de José Alsina. Traducción en verso de Fernando Gutiérrez. Barcelona, Planeta.

Arnaldo, Javier, ed. (1987): Novalis, F. Schiller, F. y A. W. Schlegel, H. von Kleist, F. HÖLDERLIN, Fragmentos para una teoría romántica del arte. Antología y edición de Javier Arnaldo. Madrid, Tecnos.

Bernabé, Alberto, ed. (2003): De Tales a Demócrito. Fragmentos presocráticos. Introducción, traducción y notas de Alberto Bernabé. Madrid, Alianza.

CANER-LIESE, Robert, ed. (2007): NovAlis, Estudios sobre Fichte y otros escritos. Edición y traducción de Robert Caner-Liese. Madrid, Akal.

EGgers Lan, Conrado, ed. (1998): Platón, República. Introducción, traducción y notas de Conrado Eggers Lan. Madrid, Gredos.

GALÍ, Neus (1999): Poesía silenciosa, pintura que habla. Barcelona, El Acantilado.

HALliwell, Stephen (2005): «The Republic's Two Critiques of Poetry (Book II 376c-398b, Book X 595a-608b)», en Ottfried HöFFE, ed., Platon. Politeia. Berlin, Akademie Verlag, pp. 313-332

JANZ, Marlies (2001/02): «“... noch nichts Interkurrierendes“. Paul Celan in Berlin im Dezember 1967», Celan-Jahrbuch 8, pp. 335-345.

MARtín SÁnCHEZ, Adelaida - MARTín SÁnCHEZ, María Ángeles, eds. (2001): Hesiodo, Teogonía. Trabajos y días. Escudo. Certamen. Introducción, traducción y notas de Adelaida Martín Sánchez y María Ángeles Martín Sánchez. Madrid, Alianza.

Martínez MarzoA, Felipe (1973): Historia de la filosofía. Filosofía antigua y medieval. Madrid, Istmo.

(1974): Iniciación a la filosofía. Madrid, Istmo, 2011.

(1990): «El sentido y lo no-pensado (Apuntes para el tema “Heidegger y los griegos")», en De Grecia y la Filosofía. Murcia, Universidad de Murcia, pp. 41-82.

- (1996): Ser y diálogo. Leer a Platón. Madrid, Istmo.

(2000): «Píndaro y el libro X de “La república” de Platón», en AA. VV., La razón del mito (I Congreso de Mitología Mediterránea). Madrid, UNED, pp. 200-208.

(2005): El saber de la comedia. Madrid, Antonio Machado Libros.

(2006): El decir griego. Madrid, Antonio Machado Libros.

(2007): Muestras de Platón. Madrid, Abada.

(2009): La cosa y el relato (A propósito de Tucídides). Madrid, Abada.

PAJEROLS, Pere, ed. (2009): Friedrich SCHLEGEL, Fragmentos seguido de Sobre la incomprensibilidad.

Traducción y notas de Pere Pajerols. Barcelona, Marbot Ediciones.

PeÑAlver Gómez, Patricio (1990): «La dialéctica platónica y la forma del saber», Er. Revista de

Filosofía 11, pp. 9-27.

Perejaume (1995): El paisatge és rodó. Vic, Eumo Editorial. (1999): Dejar de hacer una exposición. Barcelona, MACBA/ACTAR. 
- (2003): Obreda. Barcelona, Edicions 62/Empúries.

- (2011): ¡Ay Perejaume, si vieras la acumulación de obras que te rodea, no harías ninguna más! Barcelona, Fundació Caixa Catalunya.

SAINT GIROns, Baldine (2008): Lo sublime. Traducción de Juan Antonio Méndez. Madrid, Antonio Machado Libros.

SAMUEL, Richard - MÄHL, Hans-Joachim - SchUlZ, Gerhard, eds. (1981): NovALIS, Das philosophische Werk I (Schriften. Die Werke Friedrich von Hardenbergs, vol. II). Stuttgart, Kohlhammer.

Villacañas Berlanga, José Luis (1991): Los caminos de la reflexión. Del saber del Orden a la nostalgia del Bien (Historia de la Filosofía I). Murcia, Universidad de Murcia. 